\title{
1. Introduction: applications of evolutionary economic geography
}

\section{Ron A. Boschma and Koen Frenken}

\section{INTRODUCTION}

Economic geography is the field of study that deals with the uneven distribution of economic activities in space. Two conflicting theories are currently influential in the field: institutional economic geography and the 'new' economic geography. Institutional economic geography is dominated by scholars with a geography background and is akin to institutional economics (Hodgson, 1998). At the risk of oversimplification, institutional economic geography argues that the uneven distribution of wealth across territories is primarily related to differences in institutions (Whitley, 1992; Gertler, 1995; Martin, 2000). The new economic geography has been developed by neoclassical economists (Krugman, 1991; Fujita et al., 1999; Brakman et al., 2001), who view uneven distributions of economic activity as the outcome of universal processes of agglomeration driven by mobile production factors. Recent debates between geographers and economists have been fierce and with little progress (for example, Martin, 1999; Amin and Thrift, 2000; Overman, 2004). The lack of cross-fertilisation between the two disciplines can be understood from two incommensurabilities between institutional and neoclassical economics (Boschma and Frenken, 2006).

First, institutional economic geography and new economic geography differ in methodology. Institutional economic geographers tend to dismiss a priori the use of formal modelling. Instead, they apply inductive, often, casestudy research, emphasising the local specificity of 'real places'. By contrast, the new economic geography approaches the matter deductively using formal models based on 'neutral space', representative agents and equilibrium analysis. Proponents of the latter approach do not value, or even reject altogether, case-study research. Second, the two theories differ in core assumptions regarding economic behaviour. The new economic geography aims to explain geographical patterns in economic activity from utility-maximising actions of individual agents. By contrast, institutional scholars start from the 
premise that economic behaviour is best understood as being rule guided. Agents are bounded rational and rely heavily on the institutional framework, which guides their decisions and actions. Institutions are embedded in geographically localised practices, which implies that localities ('real places') are the relevant unit of analysis. Institutions play no role in neoclassical models, or only in a loose and implicit sense. They are not regarded as essential to economic explanations, and their study should therefore be 'best left to the sociologists', as Krugman once put it (Martin, 1999: 75).

Evolutionary economic geography can be considered a third approach in economic geography. Evolutionary economists argue that 'the explanation to why something exists intimately rests on how it became what it is' (Dosi, 1997: 1531). Rather than focusing on universal mobility processes underlying agglomeration (neoclassical) or the uniqueness of institutions in specific territories (institutional), an evolutionary economic geography views the economy as an evolutionary process that unfolds in space and time. In doing so, it focuses on the path-dependent dynamics underlying uneven economic development in space (Martin and Sunley, 2006). In particular, it analyses the geography of firm dynamics (such as the geography of entrepreneurship, innovation and extinction) and the rise and fall of technologies, industries, networks and institutions in different localities. In this view, uneven economic development requires an understanding of the Schumpeterian process of creative destruction at different levels of spatial aggregation (cities, regions, nations, continents).

Even though evolutionary economics goes back at least to the seminal contribution by Nelson and Winter (1982), evolutionary approaches to economic geography are fairly recent (Arthur, 1994; Swann and Prevezer, 1996; Boschma, 1997; Rigby and Essletzbichler, 1997; Storper, 1997; Boschma and Lambooy, 1999; Antonelli, 2000; Caniëls, 2000; Klepper, 2001; Maggioni, 2002; Breschi and Lissoni, 2003; Bottazzi et al., 2004; Brenner, 2004; Werker and Athreye, 2004; Boschma and Wenting, 2005; Essletzbichler and Rigby, 2005; Martin and Sunley, 2006). The difference between evolutionary economic geography and both new and institutional economic geography can be summarised as follows (Boschma and Frenken, 2006). An evolutionary approach to economic geography is different from new economic geography in that it attempts to go beyond the heroic assumptions about economic agents and the reduction of geography to transportation costs. At the same time, evolutionary economic geography also differs from institutional economic geography in that an evolutionary approach explains territorial differences not primarily by referring to different institutions, but from differences in the history of firms and industries residing in a territory. An evolutionary analysis may well take into account the role of institutions though, but in a co-evolutionary perspective (Nelson, 1995). 
Methodologically, evolutionary economic geography differs from both institutional and new economic geography in that it combines all research methodologies: case-study research, surveys, econometrics, theoretical modelling exercises and policy evaluation can, in principle, all be based on evolutionary theorising.

The present volume, Applied Evolutionary Economics and Economic Geography, aims to further develop an evolutionary economic geography. It does so by bringing together a selected group of excellent scholars coming from business studies, economics, geography, planning and organisational sociology. All contributors share an interest in explaining the uneven distribution of economic activities in space and the historical processes that have produced these patterns. The heterogeneity in backgrounds was overcome by a common understanding of the evolutionary nature of spatial processes. The end result is a volume of 13 chapters on various topics organised under the headings of entrepreneurship, industrial dynamics, network analysis, spatial systems and planning. The volume also reflects the variety of research methodologies characterising applied evolutionary economics, including case-study research (Garnsey and Heffernan, Chapter 2; Quéré, Chapter 3; Lee and Sine, Chapter 5; Bertolini, Chapter 13), duration models (Klepper, Chapter 4), data envelopment analysis (Jacob and Los, Chapter 6), complexity theory (Sorenson et al., Chapter 7), social network analysis (Sorenson et al., Chapter 7; Giuliani, Chapter 8; Birke, Chapter 9; Maggioni and Uberti, Chapter 11), spatial econometrics (Essletzbichler, Chapter 10; Bonaccorsi et al., Chapter 12) and gravity modelling (Maggioni and Uberti, Chapter 11).

\section{EVOLUTIONARY ECONOMIC GEOGRAPHY: MICRO, MESO AND MACRO APPLICATIONS}

Boschma and Frenken (2006) argued that applications of evolutionary economic geography primarily fall under four categories: firm, industry, network and spatial systems. Their scheme also underlies the structure of the book with the various chapters being organised under one of these four headings. Following Figure 1.1, the categories follow from aggregating firms to their relevant meso levels of the industry in which they compete and the networks in which they exchange commodities and share knowledge. Aggregating in turn the meso levels to the macro level, one obtains the macro level of spatial systems. Following this scheme, localities in spatial systems, be it cities, regions or countries, can be characterised by their sector composition and their position in spatial networks, and structural changes herein over time (Castells, 1996). 


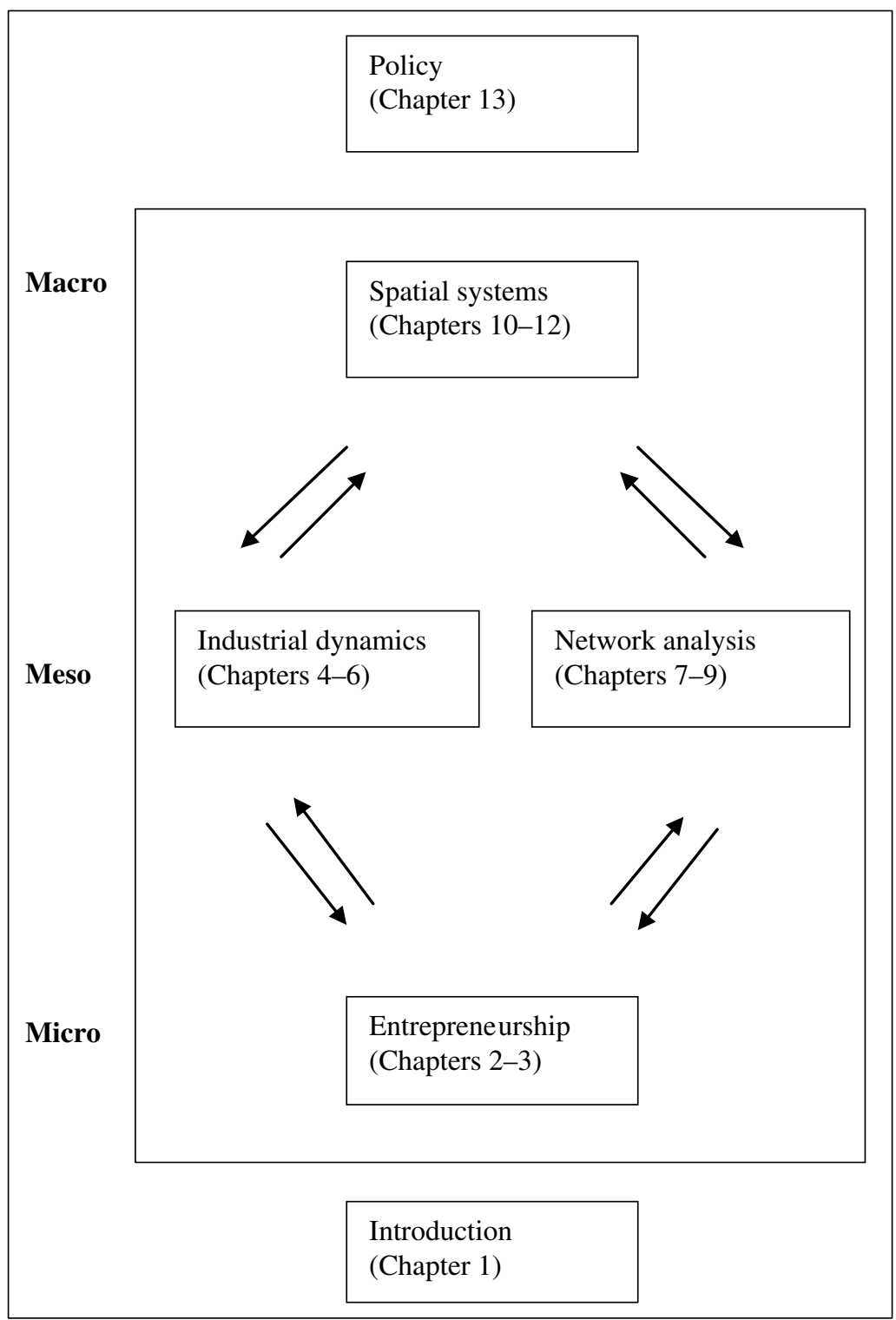

Source: Adapted from: Boschma and Frenken (2006, p. 293).

Figure 1.1 Evolutionary economic geography applied at different levels of aggregation 


\section{Entrepreneurship}

We consider evolutionary economic geography to involve a synthesis of evolutionary economics and economic geography. Following evolutionary economics, our starting point is the firm, which competes on the basis of its routines and core competences that are built up over time (Nelson and Winter, 1982). Organisational routines and core competences consist for a large part of learning-by-doing and tacit knowledge, which are hard to codify and difficult to imitate by other firms (Teece et al., 1997; Maskell, 2001). Consequently, organisations are heterogeneous in their routines, and persistently so (Klepper, Chapter 4; Giuliani, Chapter 8). Models can thus no longer rely on assuming a 'representative agent', but have to account for heterogeneous firms. This variety provides the fuel for selection processes, which causes some firms to prosper and grow and others to decline and possibly exit. From this evolutionary process of firm dynamics based on competition, innovation and selection, an emergent spatial pattern of economic activity arises. This evolving economic landscape, as reflected by spatial heterogeneity in firms' routines, can be understood as the joint outcome of geographical proximity (enhancing innovation and imitation) on the one hand, and spatial differences in selection conditions on the other (Boschma and Lambooy, 1999; Essletzbichler and Rigby, 2005).

In the context of economic geography, firm location, or more generally, the locational behaviour of firms, is the central explanandum (Stam, 2003). Demographically, the evolutionary economic process unfolding in space and time is driven by entry of new firms, exit of incumbent firms and relocation of incumbent firms. Through this process, new routines are being diffused in space. From an evolutionary perspective, one does not analyse new firm location solely as the outcome of rational decisions directed by price differentials, as in neoclassical theory, or in terms of comparing institutional frameworks in different areas, as in institutional theory. Rather, one is interested in the history of the founder and key employees of a new venture to account for routines transferred from a previous activity, and how that affects their survival. And, to understand uneven rates of regional entrepreneurship and entrepreneurial success, one is interested in the spatial distribution of resources required to start up a new business. As entrepreneurs require resources (capital, labour, networks, knowledge) to start new ventures, and resources tend to concentrate in space, as in urban areas (Hoover and Vernon, 1959) or specialised clusters (Porter, 2000), the probability of starting a new venture can also be made dependent on territorial conditions. This is not to say that price differentials (the neoclassical view) and place-specific institutions (the institutional view) do not matter. Rather, prices and institutions only condition the range of possible 
economic behaviours and their locations, while the actual behaviours are determined by the path-dependent history of actors involved in particular territorial settings (Boschma and Frenken, 2006).

The core concept of path dependence can also be fruitfully applied to firm location. Location decisions by firms are heavily constrained by the past. For example, many firms just start at locations where the founder lives, due to bounded rationality, or because the founder is socially embedded in local networks, and it is well known that most spin-offs locate near the parent firm (Cooper and Dunkelberg, 1987; Klepper, 2001). In either case, previous decisions taken in the past determine the location decision of a new firm. Path dependence also affects the probability of relocation as firms are expected to display a considerable degree of locational inertia. The probability of relocation decreases over time as a firm develops a stable set of relations with suppliers and customers and sunk costs accumulate in situ (Stam, 2003). Of course, even though path dependence constrains relocation of the firm, one can expect the firm to outsource parts of the production to low-wage locations, in particular, activities that rely less on the organisational and core competences built up in situ over time (see Vernon, 1969). The probability and economic success of off-shoring, however, depends on a firm's capability to transfer its routines to different localities (Kogut and Zander, 1993).

Research has paid special attention to the geography of high-tech entrepreneurship (Hall and Markusen, 1985; De Jong, 1987; Aydalot and Keeble, 1988; Saxenian, 1994; Stuart and Sorenson, 2003). New high-tech firms are commonly thought to fuel employment growth and regional economic development. In the present volume, we focus on two exceptional European regions that have been successful in fostering high-tech entrepreneurship in information and communication technology (ICT). The two cases concern Cambridge, UK and Sophia-Antipolis near Nice. The development of Cambridge as a high-tech region can be understood as resulting from an endogenous evolutionary process of entrepreneurs setting up business and hereby improving the conditions for new ventures to occur (Garnsey and Heffernan, Chapter 2). The endogenous process encompassed the founding of companies by members of the university, spin-offs, the rise of local suppliers and the emergence of specialist labour markets. This process, however, has not been entirely 'automatic'. Once congestion became problematic and university regulations were perceived unfavourable for entrepreneurship, collective action resulted in institutional reform. Thus, the history of the Cambridge region illustrates both the endogenous nature of entrepreneurship and the co-evolutionary process of entrepreneurship, regional development and institutional change. Another example of successful regional development is the science park of SophiaAntipolis. However, its development was far from endogenous. Rather the 
process was triggered by the presence of a few large companies, a favourable living environment and a visionary man (Quéré, Chapter 3). Interestingly, the process transformed from being triggered by external factors into a more endogenous process from the early 1990 s onwards. The endogenous nature of the more recent history is evidenced by the fact that even though some larger firms left the park in the early 1990s to go to larger agglomerations such as Paris and London, employees decided not to leave the region, but to start their own ventures instead. In this particular case, it is the employee rather than the firm that shows locational inertia. Thus, the two cases of Cambridge and SophiaAntipolis are different yet equally successful in the creation of new high-tech firms (see also, Garnsey and Longhi, 2004).

\section{Industrial Dynamics}

Starting from the firm, the first meso level of aggregation that is specifically important in evolutionary economic geography is the industry level. In this context, the main phenomenon to be explained is the process of spatial concentration or de-concentration of an industry over time. Arthur (1994) developed two simple evolutionary models of spatial concentration by spin-off and by agglomeration economies (see also, Boschma and Frenken, 2003). In the spin-off model an industry comes into being as a Polya process of firms giving birth to firms giving birth to firms and so on. This process is known to have played an important role in the rapid growth and spatial concentration of several industries, including the concentration of the US automobile industry in the Detroit area (Klepper, 2001), the ICT sector in Silicon Valley (Saxenian, 1994) and the biotechnology sector in Cambridge, UK (Keeble et al., 1999).

Klepper $(2001,2002)$ extended the spin-off model in an industry lifecycle model, which synthesises five assumptions: routines are heterogeneous; spin-offs inherit the routines of parent firms; more successful firms grow faster; larger firms produce more spin-offs; and worse-performing firms are forced to exit due to competition. The first four mechanisms ensure that the region that hosts early, experienced and successful entrants will come to dominate the industry. In contrast to Arthur's spin-off model, this truly concerns a process of inheritance in which the experience of parent firms is inherited by spin-offs with a positive impact on their survival rates. The fifth mechanism of cost competition at the sector level asymmetrically affects regions, causing the region hosting the less successful firms to decline, leaving the region hosting the successful companies to dominate the industry. Typically, cost competition becomes fierce only after an industry has developed for a number of years, that is, after product standardisation has taken place and innovation shifts to process innovation 
in line with the product life-cycle hypothesis (Abernathy and Utterback, 1978). The result is a shakeout forcing many firms to exit the industry, which strongly affects the spatial distribution of the industry since routines are heterogeneous and unevenly spread. The predictions of the model can be tested econometrically in a relatively straightforward way using duration models (Klepper, 2001, 2002).

Arthur's (1994) second model of agglomeration economies assumes that new firms start up rather than spin off from incumbent firms. The location choice of a new firm can therefore not be 'automatically' determined by the location of the parent company: the location of the firm becomes a choice decision. Arthur assumes that each firm has a locational preference for one particular region. While Arthur is far from explicit on this matter, this heterogeneity in preferences can stem from bounded rationality yet may also be given an empirical meaning: start-ups typically locate their business in the region where the founder lives and/or held previous employment. Agglomeration economies arising from spatial concentration of firms operating in the same industry, cause the industry to concentrate in one single region even though the individual firms have different individual preferences. The reason is that once one region has attracted slightly more entrants than other regions, a critical threshold is passed, and suddenly all firms will opt for this one region: a case of spatial lock-in.

In an empirical context, the outcomes of the spin-off model are not easily distinguishable from the outcomes of the agglomeration economies model. We have, indeed, two different explanations for the same phenomenon of spatial concentration of an industry. As spin-off dynamics and agglomeration economies may well contribute to spatial concentration simultaneously, the challenge for empirical research is to disentangle both processes so as to assess their presence and importance. One out of the few studies that have attempted to do so is Klepper's (2001) study of the US automobile industry. In his econometric analysis, he included a dummy for being located in the Detroit area. The dummy showed no positive effect on the survival of firms, which suggests that agglomeration economies were not present. The use of a Detroit control variable, however, can be questioned, since a subset of firms within the Detroit area may have benefited from each other's presence through local networks (Giuliani, Chapter 8) or firms may have benefited from knowledge spillovers over a longer distance (Jacob and Los, Chapter 6). Despite this shortcoming, the result by Klepper (2001) strongly suggests that the concentration of the US automobile industry in Detroit can be attributed mainly to the self-reinforcing dynamics of successful firms creating successful spin-offs, and so on.

A study by Boschma and Wenting (2005) on the spatial evolution of the British automobile sector came to similar conclusions regarding the 
self-reinforcing nature of spin-off dynamics, which, in the British case, led to a concentration in the Birmingham-Coventry area. However, Boschma and Wenting also accounted for the presence of related industries (such as coach and cycle making) in a region as a potential source of agglomeration economies, which was shown to have a positive effect on the survival rate of firms. Thus, the local presence of related industries appeared to be beneficial due to, for example, knowledge spillovers and skilled labour, yet the local presence of a high number of firms operating in the same industry turned out to be harmful due to increased competition, lowering the survival chances of new entrants. Another recent elaboration on Klepper's model is by Cantner et al. (2005), whose methodology using instrumental variable estimation allows for post-entry innovation. In doing so, the survival probabilities are not only dependent on initial conditions of entrants, but also on the research and development activities they undertake during their lifetime. These contributions suggest that survival analysis is a promising research methodology in evolutionary economic geography.

Importantly, in an evolutionary context, spatial concentration (or its absence) is not only an outcome of a process of industrial evolution, but also affects an industry's further evolution. This recursive relationship is central in another empirical tradition in industrial dynamics known as 'organisational ecology' or 'firm demography' (Hannan et al., 1995; Carroll and Hannan, 2000; Stuart and Sorenson, 2003; van Wissen, 2004). First, geographical concentration of industrial activities can generate positive feedbacks on entry rather than performance. This means that an industry can become concentrated through a self-reinforcing process of entry triggering more entry. Second, geographical concentration of firms increases the level of competition and makes entry less likely. This negative feedback set limits to spatial concentration. Typically, positive feedbacks operate at the start of an industry life cycle, while negative feedback takes over after a certain threshold of spatial concentration is passed. Interestingly, the two processes causing positive and negative feedbacks may well operate at different spatial scales depending on the type of industry (Jacob and Los, Chapter 6). In industries where demand is local and knowledge spillovers more global, one expects negative feedbacks to operate at a lower spatial level than positive feedbacks, resulting in a more even spatial distribution (Hannan et al., 1995). However, in markets where competition is global, but knowledge spillovers rather local, the reverse may well be the case.

Institutions also affect the spatial evolution of industries. From an evolutionary perspective, the question is not so much whether particular institutions triggered the development of a particular industry in a certain region, but rather how institutions have co-evolved with the emergence of a new sector (Nelson, 1995). The co-evolutionary perspective is important 
because it acknowledges that innovations leading to new sectors often require the restructuring of old institutions and the establishment of new institutions (Freeman and Perez, 1988). Examples of the co-evolution of new sectors and institutions are the rise of the synthetic dye industry in the second half of the nineteenth century in Germany (Murmann, 2003) and the evolution of the UK retail banking industry from the 1840s to the 1990s (Consoli, 2005). In their study of the spatial diffusion of the renewable energy technology, Lee and Sine (Chapter 5) also emphasise the differential institutional changes occurring in different American states.

\section{Network Analysis}

Networks provide another unit of analysis. Unlike the competitive nature of industrial dynamics, network relationships are less competitive and of a more complementary nature. One important aspect of networks in evolutionary economic geography is that these act as vehicles for knowledge spillovers. A key research question is then to determine whether knowledge diffusion and innovation is more a matter of being in the right place, in the right network, or in both (Boschma and Ter Wal, 2006). Social network analysis provides a rich toolbox for the analysis of the structure and evolution of networks (Wasserman and Faust, 1994; Carrington et al., 2005). What is more, there is a lot of interest in theorising about networks and network formation starting from the pioneering work by Granovetter (1973) and Burt (1982) to more recent, but already classic contributions of Watts and Strogatz (1998) and Barabasi and Albert (1999).

In evolutionary economics, interest in networks stems primarily from the increasing importance of networks among high-technology firms (Hagedoorn, 1993; Powell et al., 1996), while geographical studies have shown the role of networking in clusters (Uzzi, 1996; Maskell and Malmberg, 1999). The central question has been whether agents profit from simply being co-located or whether network relationships are required to carry these knowledge flows. A related question is whether geographical proximity facilitates the formation of network links. An innovative study by Breschi and Lissoni (2003) found that, using co-inventor data to indicate social networks and patent citations to indicate knowledge flows, geographical localisation of knowledge spillovers can be largely attributed to social networks and labour mobility. This study shows considerable progress over the study by Jaffe et al. (1993), who treated geographical space as a black box. The Breschi-Lissoni study suggests that geographical proximity is neither a necessary nor a sufficient condition for knowledge spillovers to occur. Rather, knowledge diffuses through social networks, which are dense between proximate actors, but also span across the globe. 
Network analysis between firms in specialised clusters is another field in which social network analysis can be fruitfully applied. Using survey data, Giuliani (2005) has been able to map the business and knowledge networks among wine producers in three different clusters. She found that the the distribution of connectivity is much more skewed in knowledge than in business networks, which suggests that only a few central firms profit from knowledge spillovers. This hypothesis has been put to the test in a followup study presented in this volume (Giuliani, Chapter 8), in which it is shown that a firm's centrality in knowledge networks is indeed positively affecting innovative performance, even after controlling for heterogeneity in internal competencies. A recent study by Boschma and Ter Wal (2006) on a footwear district in southern Italy tends to suggest that the absorptive capacity of firms is indirectly related to their innovative performance, through having non-local instead of local relationships. That is, the higher the absorptive capacity of a district firm, the better it is connected to organisations outside the district, which, in turn, impacts positively on their innovative performance. These studies show that social network analysis is a powerful tool in analysing the geography and structure of knowledge networks and the effect of a firm's network position in these networks on its performance. In a similar fashion, the concept of regional innovation systems (Cooke et al., 1998) can be operationalised empirically more systematically by mapping the various network relations of actors that are part of the regional system with other actors within and outside the regional system.

Evolutionary theorising has also argued that, due to bounded rationality, consumers also rely on personal networks. As a result, certain decisions by central actors can propagate through the network, leading many consumers to opt for the same product (Cowan et al., 1997; Plouraboue et al., 1998; Solomon et al., 2000). The strength of these networks effects, and the geographical nature of such personal networks, can also be explored empirically using social network analysis. A nice example of such an approach is the study by Birke (Chapter 9), who conducted a survey among students asking them about their personal networks and their choice of mobile telephone operator so as to analyse the effect of personal networks on the choice of operator.

Hitherto, the use of social network analysis in evolutionary economics has been almost exclusively static. A future challenge is to understand the spatial evolution of networks. This requires longitudinal data and methods to analyse the dynamics of networks over time. An influential theoretical model of network dynamics is the model by Barabasi and Albert (1999). In this model, a network grows as new nodes connect to a network. Nodes are assumed to attach themselves to other nodes with a probability proportional 
to the latter's connectivity. This principle is known as 'preferential attachment', which means that a new node prefers to link with a well-connected node so as to profit from its connectivity. Well-connected nodes will then tend to become even more connected, while peripheral nodes in the network will tend to remain peripheral. The resulting distribution of connectivity will be extremely skewed (scale free). Which of the nodes becomes the central node is path dependent, and thus unpredictable, although early entrants will have a much higher probability of becoming central than later entrants. The stochastic logic underlying the Barabasi-Albert model of network formation has also been applied to the spatial evolution of networks where new nodes can occur anywhere in space, and connections between nodes are made dependent on both geographical space (negatively) and preferential attachment (positively). The resulting topology and spatial organisation of a network can then be understood as a purely stochastic and myopic sequence (Andersson et al., 2003, 2006) that may generate hub-and-spokes networks, as observed in infrastructure networks (for example, Guimerà and Amaral, 2004; Barrat et al., 2005). Empirical research in this field, however, has still been rather limited.

\section{Spatial Systems}

Aggregating sectors and networks to the macro level of spatial systems, one obtains a model of the growth of localities (cities, regions, countries), as depending on their sectoral composition and global network position, and the structural changes herein occurring over time. The sectoral logic underlying the evolution of spatial systems is better known as the process of structural change (Freeman and Perez, 1988; Boschma, 1997, 2004). Cities and regions that are capable of generating new sectors with new product life cycles will experience growth, while cities and regions that are locked into earlier specialisations with mature life cycles will experience decline. Importantly, there is no automatic economic or political mechanism to ensure that cities or regions will successfully renew themselves. Rather, one expects localities in most instances to experience decline after periods of growth due to vested interests, institutional rigidities and sunk costs associated with previous specialisations (Grabher, 1993). There are, however, still very few systematic evolutionary studies on convergence and divergence at different spatial scales (for example, Pumain and MoriconiEbrard, 1997; Caniëls, 2000). This can be partly understood from the demanding data requirements for systematic analysis of long-term dynamics, especially if one is interested in analyses at subnational levels.

A particularly popularly topic in economic geography concerns the role of variety in regional growth. Economic theory has long been focused on 
explaining economic growth by a combination of growth in inputs and efficiency improvements (Solow, 1957). The underlying qualitative nature of economic development, in terms of the variety of sectors or the variety of technologies, has been addressed only rarely. One can distinguish three types of relationships between variety and economic development (Frenken et al., 2005, 2006). The first approach centres on variety, knowledge spillovers and growth, which has become a central theme in what is called 'new growth theory'. It has been argued that, apart from spillovers occurring between firms within a sector, spillovers also occur between sectors, which are commonly referred to as 'Jacobs externalities', after Jacobs (1969). A second way to relate variety to regional economic development is to view variety as a portfolio strategy to protect a region from external shocks in demand (Essletzbichler, Chapter 10). In this context, one also speaks of regional diversification analogous to corporate diversification as a risk-spreading strategy. A third type of relationship between variety and economic development concerns the long-term effect of variety on the economic system. An economy that does not increase the variety of sectors over time, will suffer from structural unemployment, and will ultimately stagnate. In this view, the development of new technologies and sectors in an economy is required to absorb labour that has become redundant in existing sectors (Pasinetti, 1981, 1993; Saviotti and Pyka, 2004). This process underlying long-term growth has major geographical implications, when new sectors emerge in other areas than the ones where old sectors are located. This would imply that labour becomes redundant primarily in areas where the old sectors are concentrated, while new employment is primarily created in new areas. This imbalance may be counteracted by labour migration from old to new areas and by firm migration in the opposite direction.

Although many empirical studies have analysed the effects of variety on regional growth in the past decade or so, some methodological issues in empirical research remain. First, the measurement of variety is not trivial. For example, one would like to distinguish between related variety underlying spillovers and unrelated variety underlying the portfolio effects (Frenken et al., 2006; Essletzbichler, Chapter 10). Second, explaining regional phenomena requires a careful econometric specification so as to allow different effects to take place at different spatial levels of aggregation. For example, the rate of regional growth or the rate of regional information technology (IT) adoption can be made dependent on the rate of growth in neighbouring regions through the use of spatial autocorrelation econometrics (Essletzbichler, Chapter 10; Bonaccorsi et al., Chapter 12).

The network perspective also lends itself for aggregation to the macro level. By aggregating networks between firms to the locations of these firms, one obtains inter-city and inter-regional networks. The underlying concept 
of 'network cities' has become very common among geographers (Pred, 1977; Hohenberg and Lees, 1995; Castells, 1996). The central idea underlying the concept of network cities holds that connectivity contributes both to urban economic growth and to urban inequalities. Examples of empirical studies that map urban networks include networks based on the ties between headquarters and subsidiaries of multinational organisations (Taylor, 2001; Alderson and Beckfield, 2004), on transportation networks (Matsumoto, 2004) or IT infrastructure (Moss and Townsend, 2000). In these views, cities can develop a more central network position by attracting corporate headquarters or functioning as transportation or IT hubs. The concept of inter-city networks can also be applied to inter-regional networks, as the contribution by Maggioni and Uberti (Chapter 11) shows. Regions acting as central hubs in the development and diffusion of knowledge will be more central in these networks, while other regions will stay more peripheral. Network position is thus expected to affect regional growth, as central hubs will receive more, and more relevant, knowledge spillovers. Using Tinbergen's (1962) gravity model from international trade theory, one can also analyse to what extent geographical distance affects the strength of knowledge flows between any two regions. This question has also been taken up by Maggioni and Uberti (Chapter 11).

As for the study of firm networks, the dynamic analysis of urban and regional networks is still in its infancy. Understanding the structure of a network at one moment in time requires an understanding of the evolutionary process that has given rise to such structures. An interesting research avenue is to analyse the determinants of changes in network structures in a spatial system. For example, does the accession of Eastern European countries reorganise the hierarchy in the European city system? And, historically, can we relate the rise and fall of cities to their changing positions in global knowledge networks around emerging technologies and infrastructures (Pumain, 1997)?

\section{POLICY}

The contributions in the present volume focus on understanding spatial phenomena from an evolutionary perspective. General policy implications are often hard to draw, if only because evolutionary theorising leaves room for 'small events' to have long-lasting effects. Some may even go a step further to suggest that evolutionary analysis often shows the limited potential of policy makers to truly influence long-term geographical patterns of economic growth. For example, Klepper's (Chapter 4) conclusion that the US automobile industry became concentrated in Detroit for accidental 
reasons, suggests that efforts to attract new industries to a particular city or region have a low probability of success. What matters most is to have competent entrepreneurs, the presence and actions of which are hard to influence by policy. Similarly, the success story of Sophia Antipolis (Quéré, Chapter 3) suggests that its success is unique and difficult to copy. The process of regional development was set in motion by external factors such as climate, the presence of multinationals, the international airport, and one visionary man. And, in the case of Cambridge, regional development was fuelled by its excellent university as well as by the benefits of the Greater London area at just one hour from Cambridge (Garnsey and Heffernan, Chapter 2).

Even if policy implications of evolutionary economics are inherently difficult to derive, a growing number of evolutionary economists are trying to draw some policy implications (Perez and Soete, 1988; Metcalfe, 1995; Foray, 1997; Nelson, 1999; Lambooy and Boschma, 2001; Chang, 2003). The point of departure is that the focus on static efficiency in neoclassical economics is to be replaced by dynamic efficiency (Nelson and Winter, 1982). In other words, one is not only interested in the allocation of scarce resources present today, but also in the opportunities to create new resources in the future.

In the context of economic geography, the question becomes how to design policies that promote dynamic efficiency at urban and regional levels. Boschma (2005) distinguished between two types of regional policy: evolutionary and revolutionary (Table 1.1). Evolutionary regional policy takes the specific local context and industrial structure as the starting point. It is a fine-tuning policy that aims to strengthen the connectivity between the elements of the regional system. In these circumstances, local policy makers have few degrees of freedom, yet are more likely to be successful as long as their actions are localised, that is, focused on reproducing and strengthening the existing structures. In other words, the local environment

Table 1.1 Two types of regional innovation policy

\begin{tabular}{ll}
\hline Evolutionary type of policy & Revolutionary type of policy \\
\hline Location-specific policy & Generic policy \\
Fine-tuning & Restructuring of institutional framework \\
Strengthening existing connectivity & Stimulating new connections \\
Benefiting from specialisation & Stimulating diversity \\
Few degrees of freedom & More degrees of freedom \\
Less uncertainty & More uncertainty \\
\hline
\end{tabular}

Source: Adapted from Boschma (2005). 
determines to a large extent available options and probable outcomes of regional policy.

The goal of a revolutionary regional policy, by contrast, is the restructuring of the social and institutional framework by constructing new regional systems, increasing diversity and a high degree of openness regarding the inflow of labour, capital and knowledge. In these circumstances, local policy makers have more degrees of freedom, but at the cost of a higher degree of uncertainty regarding the actual outcome of regional policy making and its success. Since path dependence is less relevant, it is less meaningful to account for the location-specific context as a starting point for regional policy. Radically new trajectories of industrial development build on generic conditions, because the existing actors and institutional environment are unlikely to provide the specific stimuli. The case of Sophia Antipolis seems to be a good example of such a development.

The paradox of regional policy holds that it can be very effective and successful in conserving economic activity by means of evolutionary policies, yet it has difficulty triggering, or even opposes new economic activity necessary for long-term development. Note, however, that evolutionary and revolutionary policies are not mutually exclusive. One can pursue finetuning policies in existing sectors while improving the generic conditions for revolutionary change to take place. However, such a two-goal policy requires careful policy making, because policies designed for one goal may in practice hamper the achievement of the other one. A way to combine both objectives is to enhance the creation of new industrial trajectories, be it new technologies or new sectors, by means of building upon the existing competence base of firms, employers and employees in the region. Radical innovations often stem from the (quite unexpected) recombination of existing technologies in entirely new ways (Levinthal, 1998). A famous example has been the rise of an environmental sector after the decline of the mining industry in the Ruhr area. A broad engineering base in the Emilia Romagna region provided a fertile ground for the emergence of a broad range of industries such as ceramics, food packaging, robotics, car manufacturing and agricultural machinery during the post-war period (Boschma, 2004). Another example is the birth of the automobile industry in the Coventry-Birmingham area in England, which was partly determined by the strong presence of the bicycle and carriage industry (Boschma and Wenting, 2005). This policy captures the importance of creating 'related variety' in a region, which broadens a region's sectoral base, while fostering knowledge spillovers between the sectors (Frenken et al., 2005, 2006).

Another domain of policy, which is of crucial importance for urban and regional economic growth, is infrastructure provision. The growth of agglomerations is limited by the capacity and quality of its infrastructure 
networks. For this reason, successful regional policy always requires a complementary transportation infrastructure policy. Again, Sophia Antipolis serves as a successful example (Quéré, Chapter 3), while Cambridge suffered precisely from a mismatch between its economic development and infrastructure provision (Garnsey and Heffernan, Chapter 2). Adopting an evolutionary approach to transportation planning in the agglomeration of Amsterdam, Bertolini (Chapter 13) attempts to derive some general guidelines for planning. Given the inherent and irreducible uncertainty about the future regional development and landuse claims, urban transportation systems should be capable of resilience, that is, still function properly in the face of change. At the same time, if necessary, the system must also be responsive to change, that is, it must be adaptable. In transport systems, resilience is best shown by the network morphology and multi-modality, while adaptability is foremost a property

of the policy system. The link between the two is important: in the case of Amsterdam, the resilience of the transport network morphology has been a condition for the adaptability of land use and mobility management policies, because it allowed a choice at all times between substantially different policy courses.

\section{DISCUSSION}

Using the micro-meso-macro scheme in Figure 1.1 as a framework, we have discussed various applications of evolutionary economics in the field of economic geography. The common denominator in these approaches is to view spatial structures as the outcome of historical processes, and as conditioning but not fully determining economic behaviour. The explicit historical nature of evolutionary analysis, however, poses demanding requirements for empirical research. One needs to collect time-series data of evolving populations, be it from technologies, sectors, networks, cities or regions, and to apply appropriate methodologies to analyse the data collected. The contributions by Klepper (Chapter 4), Jacob and Los (Chapter 6) and Essletzbichler (Chapter 10) are fine examples of the use of econometric techniques applied to time-series data. However, other methodologies are also available to fruitfully apply evolutionary economics. For example, case-study research, combining written and oral sources, can provide an understanding of long-term planning processes (Bertolini, Chapter 13) and the multi-faceted process of regional development (Garnsey and Heffernan, Chapter 2; Quéré, Chapter 3). Static analysis, although dealing with snapshots of an otherwise evolving process, can also be approached from an evolutionary perspective, for example, by deriving 
hypotheses on expected inequalities in network positions (Giuliani, Chapter 8) or rates of technology adoption (Bonaccorsi et al., Chapter 12). Nevertheless, such phenomena could be understood better if time-series data were available.

Apart from data limitations and methodological challenges ahead, there are still a number of conceptual weaknesses that hamper the application of evolutionary economics to economic geography: for example, the concept of routines still needs to be refined (Becker, 2004), and their role in the development of multi-locational organisations is still quite unclear (Stam, 2003, 2006); and the evolutionary theory of the firm has little to say about multinational organisations, exceptions aside (Kogut and Zander, 1993; Cantwell and Iammarino, 2003). Another key concept in evolutionary economics is path dependence. Yet, its fruitful application in economic geography is still surrounded by a number of unsolved issues (Martin and Sunley, 2006). Finally, as Breschi and Lissoni (2001) have argued at length, the concept of knowledge spillovers is, both conceptually and empirically, still ill-defined. Despite the growing number of studies on knowledge spillovers, the mechanisms underlying such spillovers are still poorly understood as well as to what extent these mechanisms are sector and/or region specific. Furthermore, the importance of knowledge spillovers may be specific for the geographical distance over which they occur. The more important information flows typically stem from more distant locations, a geographical principle that might reflect the strength of weak ties (Granovetter, 1973). However, research that takes into account global spillovers is still scarce (Jaffe and Trajtenberg, 1999). In this light, the contributions by Jacob and Los (Chapter 6) and Maggioni and Uberti (Chapter 11) are especially important.

The 'big question' regarding the unequal distribution of wealth among nations needs to be addressed more often and more systematically. An evolutionary economic geography may provide a new understanding of core-periphery patterns at different spatial scales as evolutionary outcomes of path-dependent dynamics. Such an approach would combine the Schumpeterian analysis of structure change with the spatial process of agglomeration and global networking. However, evolutionary growth theory (as does growth theory more generally) still lacks an explicit spatial structure. A challenge ahead is to transform evolutionary growth theory into a theory explaining the evolution of uneven distribution of economic activities in space.

In all, recent research, including the chapters in this volume, has shown the value added of an evolutionary approach in economic geography. An evolutionary economic geography aims to improve our theoretical and empirical understanding of the economy as an evolutionary process that 
unfolds in space and time. Starting from the seminal contribution by Nelson and Winter (1982) and its theoretical elaborations in subsequent works (Dosi et al., 1988; Dopfer, 2005), a number of frameworks are being developed that specifically deal with geographical issues, including location theory and entrepreneurship, the spatial evolution of sectors, the geography of social networks, the evolution of spatial systems, and urban and regional planning. Methodologically, a variety of approaches are being pursued ranging from case-study research and social network analysis to duration models and spatial econometrics. Theoretically coherent and methodologically open, an evolutionary perspective is helpful in understanding the specific histories of firms and regions using a framework that is less restrictive than the neoclassical paradigm, yet more generally applicable than the institutionalist approach. It is time to take geography seriously in applied evolutionary economics.

\section{BIBLIOGRAPHY}

Abernathy W.J. and Utterback, J. (1978), 'Patterns of industrial innovation', Technology Review, 50: 41-7.

Alderson, A.S. and Beckfield, J. (2004), 'Power and position in the world city system', American Journal of Sociology, 109: 811-51.

Amin, A. and Thrift, N. (2000), 'What kind of economic theory for what kind of economic geography?', Antipode, 32(1): 4-9.

Andersson, C., Frenken, K. and Hellervik, A. (2006), 'A complex network approach to urban growth', Environment and Planning A, 38: 1941-64.

Andersson, C., Hellervik, A., Lindgren, K., Hagson, A. and Tornberg, J. (2003), 'Urban economy as a scale-free network', Physical Review E, 68(3): 036124 Part 2.

Antonelli, C. (2000), 'Collective knowledge communication and innovation: the evidence of technological districts', Regional Studies, 34(6): 535-47.

Arthur, W.B. (1994), Increasing Returns and Path Dependence in the Economy, Ann Arbor, MI: University of Michigan Press.

Aydalot, P. and Keeble, D. (eds) (1988), High Technology Industry and Innovative Environments: The European Experience, London and New York: Routledge.

Barabasi, A.L. and Albert, R. (1999), 'Emergence of scaling in random networks', Science, 286(5439): 509-12.

Barrat, A., Barthelemy, M. and Vespignani, A. (2005), 'The effects of spatial constraints on the evolution of weighted complex networks', Journal of Statistical Mechanics, Art. No. P05003.

Becker, M.C. (2004), 'Organizational routines. A review of the literature', Industrial and Corporate Change, 13(4): 643-77.

Boschma, R.A. (1997), 'New industries and windows of locational opportunity. A long-term analysis of Belgium', Erdkunde, 51: 12-22.

Boschma, R.A. (2004), 'Competitiveness of regions from an evolutionary perspective', Regional Studies, 38(9): 1001-14.

Boschma, R.A. (2005), 'Rethinking regional innovation policy. The making and breaking of regional history', in G. Fuchs and P. Shapira (eds), Rethinking 
Regional Innovation and Change: Path Dependency or Regional Breakthrough?, Dordrecht: Springer, pp. 249-71.

Boschma, R.A. and Frenken, K. (2003), 'Evolutionary economics and industry location', Review of Regional Research, 23: 183-200.

Boschma, R.A. and Frenken, K. (2006), 'Why is economic geography not an evolutionary science? Towards an evolutionary economic geography', Journal of Economic Geography, 6(3): 273-302.

Boschma, R.A. and Lambooy, J.G. (1999), 'Evolutionary economics and economic geography', Journal of Evolutionary Economics, 9: 411-29.

Boschma, R.A. and Ter Wal, A.L.J. (2006), 'Knowledge networks and innovative performance in an industrial district. The case of a footwear district in the south of Italy', Industry and Innovation, forthcoming.

Boschma, R.A. and Wenting, R. (2005), 'The spatial evolution of the British automobile industry', Papers in Evolutionary Economic Geography 05.04, http:// econ.geog.uu.nl.

Bottazzi, G., Dosi, G., Fagiolo, G. and Secchi, A. (2004), 'Sectoral and geographical specificities in the spatial structure of economic activities', Laboratory of Economics and Management (LEM) Working Paper 2004-21, www.lem. sssup.it/.

Brakman, S., Garretsen, H. and Marrewijk, C. van (2001), An Introduction to Geographical Economics, Cambridge: Cambridge University Press.

Brenner, T. (2004), Local Industrial Clusters. Existence, Emergence and Evolution, London and New York: Routledge.

Breschi, S. and Lissoni, F. (2001), 'Knowledge spillovers and local innovation systems: a critical survey', Industrial and Corporate Change, 10(4): 975-1005.

Breschi, S. and Lissoni, F. (2003), 'Mobility and social networks: localised knowledge spillovers revisited', Centre of Research on Innovation and Internationalization (CESPRI) Working Paper 142, www.cespri.unibocconi.it/.

Burt, R.S. (1982), Toward a Structural Theory of Action: Network Models of Social Structure, Perception, and Action, New York: Academic Press.

Caniëls, M. (2000), Knowledge Spillovers and Economic Growth. Regional Growth Differentials across Europe, Cheltenham, UK and Northampton, MA, USA: Edward Elgar.

Cantner, U. Dreßler, K. and Krüger, J.J. (2005), 'Knowledge compensation in the German automobile industry', Jenaer Schriften zur Wirtschaftswissenschaft, $11 / 2005$.

Cantwell, J.A. and Iammarino, S. (2003), Multinational Corporations and European Regional Systems of Innovation, London: Routledge.

Carrington, P.J., Scott, J. and Wasserman, S. (eds) (2005), Models and Methods in Social Network Analysis, Cambridge: Cambridge University Press.

Carroll, G.R. and Hannan, M.T. (2000), The Demography of Corporations and Industries, Princeton, NJ: Princeton University Press.

Castells, M. (1996), The Rise of the Network Society, Oxford: Blackwell.

Chang, H.-J. (2003), 'Kicking away the ladder: infant industry promotion in historical perspective', Oxford Development Studies, 31(1): 21-32.

Consoli, D. (2005), 'The dynamics of technological change in UK retail banking services. An evolutionary perspective', Research Policy, 34: 461-80.

Cooke, P., Uranga, M.G. and Extebarria, G. (1998), 'Regional innovation systems: an evolutionary perspective', Environment and Planning A, 30: 1563-84. 
Cooper, A.C. and Dunkelberg, W.C. (1987), 'Entrepreneurial research: old questions, new answers and methodological issues', American Journal of Small Business, 11: 11-23.

Cowan, R., Cowan, W. and Swann, G.M.P. (1997), 'A model of demand with interactions among consumers', International Journal of Industrial Organization, 15(6), 711-32.

De Jong, M.W. (1987), New Economic Activities and Regional Dynamics, Netherlands Geographical Studies no. 38, Amsterdam: Royal Netherlands Geographical Society.

Dopfer, K. (ed.) (2005), Evolutionary Principles of Economics, Cambridge: Cambridge University Press.

Dosi, G. (1997), 'Opportunities, incentives and the collective patterns of technological change', Economic Journal, 107(444): 1530-47.

Dosi, G., Freeman, C., Nelson, R., Silverberg, G. and Soete, L. (eds) (1988), Technical Change and Economic Theory, London: Pinter.

Essletzbichler, J. and Rigby, D.L. (2005), 'Competition, variety and the geography of technology evolution', Tijdschrift voor Economische en Sociale Geografie, 96(1): 48-62.

Foray, D. (1997), 'The dynamic implications of increasing returns: Technological change and path dependent inefficiency', International Journal of Industrial Organization, 15(6): 733-52.

Freeman, C. and Perez, C. (1988), 'Structural crisis of adjustment, business cycles and investment behaviour', in Dosi et al. (eds), pp. 38-66.

Frenken, K., van Oort, F.G., Verburg, T. and Boschma, R.A. (2005), 'Variety and regional economic growth in the Netherlands', Papers in Evolutionary Economic Geography 05.02, http://econ.geog.uu.nl.

Frenken, K., van Oort, F.G. and Verburg, T. (2006), 'Related variety, unrelated variety and regional economic growth', Regional Studies, forthcoming.

Fujita, M., Krugman, P. and Venables, A.J. (1999), The Spatial Economy. Cities, Regions and International Trade, Cambridge, MA: MIT Press.

Garnsey, E. and Longhi, C. (2004), 'Complex processes and innovative places: the evolution of high tech Cambridge and Sophia-Antipolis', International Journal of Technology Management, 28(3-6): 336-55.

Gertler, M.S. (1995), "Being there": proximity, organization, and culture in the development and adoption of advanced manufacturing technologies', Economic Geography, 71: 1-26.

Giuliani, E. (2005), 'The structure of cluster knowledge networks: uneven and selective, not pervasive and collective', Danish Research Unit for Industrial Dynamics (DRUID) Working Paper 2005-11, www.druid.dk.

Grabher, G. (1993), 'The weakness of strong ties: the lock-in of regional development in the Ruhr area', in G. Grabher (ed.), The Embedded Firm: On the SocioEconomics of Interfirm Relations, London and New York: Routledge, pp. 255-78.

Granovetter, M. (1973), 'The strength of weak ties', American Journal of Sociology, 78(6): $1360-80$.

Guimerà, R. and Amaral, L.A.N. (2004), 'Modelling the world-wide airport network', European Physical Journal B, 38(2): 381-5.

Hagedoorn, J. (1993), 'Understanding the rationale of strategic technology', Strategic Management Journal, 14(5): 371-85.

Hall, P.G. and Markusen, A.R. (eds) (1985), Silicon Landscapes, Boston, MA: Allen \& Unwin. 
Hannan, M.T., Carroll, G.R., Dundon, E.A. and Torres, J.C. (1995), 'Organizational evolution in a multinational context: entries of automobile manufacturers in Belgium, Britain, France, Germany, and Italy', American Sociological Review, 60(4): 509-28.

Hodgson, G.M. (1998), 'The approach of institutional economics', Journal of Economic Literature, 36(1): 166-92.

Hohenberg, P.M. and Lees, L.H. (1995), The Making of Urban Europe 1000-1994, Cambridge, MA: Harvard University Press.

Hoover, E.M. and Vernon, R. (1959), Anatomy of a Metropolis: The Changing Distribution of People and Jobs in New York Metropolitan Region, Cambridge, MA: Harvard University Press.

Jacobs, J. (1969), The Economy of Cities, New York: Vintage Books.

Jaffe, A.B. and Trajtenberg, M. (1999), 'International knowledge flows: evidence from patent citations', Economics of Innovation and New Technology, 8: 105-36.

Jaffe, A.B., Trajtenberg, M. and Henderson, R. (1993), 'Geographic localization of knowledge spillovers as evidenced by patent citations', Quarterly Journal of Economics, 108(3): 577-98.

Keeble D., Lawson, C., Moore, B. and Wilkinson, F. (1999), 'Collective learning processes, networking and "institutional thickness" in the Cambridge region', Regional Studies, 33(4): 319-32.

Klepper, S. (2001), 'The evolution of the U.S. automobile industry and Detroit as its capital', Paper presented at 9th Congress of the International Joseph A. Schumpeter Society, Gainesville, FL, March.

Klepper, S. (2002), 'The capabilities of new firms and the evolution of the U.S. automobile industry', Industrial and Corporate Change, 11(4): 645-66.

Kogut, B. and Zander, U. (1993), 'Knowledge of the firm and the evolutionary theory of the multinational corporation', Journal of International Business Studies, 24: 625-46.

Krugman, P.R. (1991), 'Increasing returns and economic geography', Journal of Political Economy, 99(3): 483-99.

Lambooy, J.G. and Boschma, R.A. (2001), 'Evolutionary economics and regional policy', Annals of Regional Science, 35: 113-31.

Levinthal, D.A. (1998), 'The slow pace of rapid technological change: Gradualism and punctuation in technological change', Industrial and Corporate Change, 7: 217-47.

Maggioni, M.A. (2002), Clustering Dynamics and the Location of High-Tech-Firms, Springer: Heidelberg.

Martin, R. (1999), "The new "geographical turn" in economics: some critical reflections', Cambridge Journal of Economics, 23(1): 65-91.

Martin, R. (2000), 'Institutional approaches in economic geography', in E. Sheppard and T.J. Barnes (eds), A Companion to Economic Geography, Oxford and Malden, MA: Blackwell, pp. 77-94.

Martin, R. and Sunley, P. (2006), 'Path dependence and regional economic evolution', Papers in Evolutionary Economic Geography 06.06, http://econ. geog. uu.nl.

Maskell, P. (2001), 'The firm in economic geography', Economic Geography, 77(4): 329-44.

Maskell, P. and Malmberg, A. (1999), 'Localised learning and industrial competitiveness', Cambridge Journal of Economics, 23(2): 167-86.

Matsumoto, H. (2004), 'International urban systems and air passenger and cargo flows: some calculations', Journal of Air Transport Management, 10(4): 239-47. 
Metcalfe, J.S. (1995), 'Technology systems and technology policy in an evolutionary framework', Cambridge Journal of Economics, 19: 25-46.

Moss, M.L. and Townsend, A.M. (2000), 'The Internet backbone and the American metropolis', The Information Society, 16: 35-47.

Murmann, J.P. (2003), Knowledge and Competitive Advantage: The Co-evolution of Firms, Technology, and National Institutions, Cambridge: Cambridge University Press.

Nelson, R.R. (1995), 'Co-evolution of industry structure, technology and supporting institutions, and the making of comparative advantage', International Journal of the Economics of Business, 2(2): 171-84.

Nelson, R.R. (1999), 'The sources of industrial leadership: a perspective on industrial policy', De Economist, 147: 1-18.

Nelson, R.R. and Winter, S.G. (1982), An Evolutionary Theory of Economic Change, Cambridge, MA and London: Belknap Press.

Overman, H.G. (2004), 'Can we learn anything from economic geography proper?', Journal of Economic Geography, 4: 501-16.

Pasinetti, L.L. (1981), Structural Change and Economic Growth, Cambridge: Cambridge University Press.

Pasinetti, L.L. (1993), Structural Economic Dynamics, Cambridge: Cambridge University Press.

Perez, C. and Soete, L. (1988), 'Catching up in technology: entry barriers and windows of opportunity', in Dosi et al. (eds), pp. 458-77.

Phelps, N.A. (2004), 'Clusters, dispersion and the spaces in between. For an economic geography of the banal', Urban Studies, 41(5-6): 971-89.

Plouraboue, F., Steyer, A. and Zimmerman, J.-B. (1998), 'Learning induced criticality in consumers' adoption pattern: a neural network approach', Economics of Innovation and New Technology, 6: 73-90.

Porter, M.E. (2000), 'Location, competition, and economic development: local clusters in a global economy', Economic Development Quarterly, 14: 15-34.

Powell, W.W., Koput, K.W. and SmithDoerr, L. (1996), 'Interorganizational collaboration and the locus of innovation: networks of learning in biotechnology', Administrative Science Quarterly, 41(1): 116-45.

Pred, A. (1977), City-Systems in Advanced Economies, London: Hutchinson.

Pumain, D. and Moriconi-Ebrard, F. (1997), 'City size distributions and metropolisation', Geojournal, 43(4): 307-14.

Rigby, D.L. and Essletzbichler, J. (1997), 'Evolution, process variety, and regional trajectories of technological change in US manufacturing', Economic Geography, 73(3): 269-84.

Saviotti, P.P. and Pyka, A. (2004), 'Economic development by the creation of new sectors', Journal of Evolutionary Economics, 14(1): 1-35.

Saxenian, A. (1994), Regional Advantage, Cambridge, MA: Harvard University Press.

Solomon, S., Gerard, W., de Arcangelis, L., Jan, N. and Stauffer, D. (2000), 'Social percolation models', Physica A, 277: 239-47.

Solow, R.M. (1957), 'Technical change and the aggregate production function', Review of Economics and Statistics, 39: 312-20.

Stam, E. (2003), 'Why butterflies don't leave: locational evolution of evolving enterprises', Dissertation, Utrecht University.

Stam, E. (2006), 'A process model of locational change: implications for an evolutionary economic geography, in A. Pyka and H. Hanusch (eds), Applied 
Evolutionary Economics and the Knowledge-Based Economy, Cheltenham UK and Northampton, MA, USA: Edward Elgar, pp. 143-65.

Storper, M. (1997), The Regional World: Territorial Development in a Global Economy, London: Guilford Press.

Stuart, T. and Sorenson, O. (2003), 'The geography of opportunity: spatial heterogeneity in founding rates and the performance of biotechnology firms', Research Policy, 32(2): 229-53.

Swann, P. and Prevezer, M. (1996), 'A comparison of the dynamics of industrial clustering in computing and biotechnology', Research Policy, 25: 1139-57.

Taylor, P.J. (2001), 'Specification of the world city network', Geographical Analysis, 33: $181-94$.

Teece, D., Pisano, G. and Shuen, A. (1997), 'Dynamic capabilities and strategic management', Strategic Management Journal, 18(7): 509-33.

Tinbergen, J. (1962), Shaping the World Economy: Suggestions for an International Economic Policy, New York: 20th Century Fund.

Uzzi, B. (1996), 'The sources and consequences of embeddedness for the economic performance of organizations: the network effect', American Sociological Review, 61(4): 674-98.

Vernon, R. (1969), 'International investment and international trade in the product life-cycle', Quarterly Journal of Economics, 80: 190-207.

van Wissen, L. (2004), 'A spatial interpretation of the density dependence model in industrial demography', Small Business Economics, 22(3-4): 253-64.

Wasserman, S. and Faust, K. (1994), Social Network Analysis: Methods and Applications, Cambridge: Cambridge University Press.

Watts, D.J. and Strogatz, S.H. (1998), 'Collective dynamics of "small-world" networks', Nature, 393: 440-42.

Werker, C. and Athreye, S. (2004), 'Marshall's disciples: knowledge and innovation driving regional economic development and growth', Journal of Evolutionary Economics, 14: 505-23.

Whitley, R. (1992), Business Systems in East Asia: Firms, Markets and Societies, London: Sage. 